\title{
12. GEOCHEMISTRY AND MINERALOGY OF SELECTED CARBONACEOUS CLAYSTONES IN THE LOWER CRETACEOUS FROM THE BLAKE-BAHAMA BASIN, NORTH ATLANTIC ${ }^{1}$
}

\author{
Hideo Kagami and Toshio Ishizuka, Ocean Research Institute, University of Tokyo, Tokyo, Japan \\ and \\ Saburo Aoki, Natural Science Institute, Toyo University, Tokyo, Japan
}

\begin{abstract}
Four dominant depositions of carbonaceous claystones are recognized to have occurred during the early Aptian to middle Albian at Site 534. There are correlations of stable isotope ratios with organic carbon content and of clay content with clay mineralogy of the samples. Almost all organic carbon in these sequences has very negative terrestrial isotope ratios, and the clay of that age indicates predominance of aluminous montmorillonite, which is thought to be of terrigenous origin. It is suggested that development of coastal vegetation belts and deltaic outbuilding with consequent outpouring of land-plant detritus and terrigenous clastics into the deep basins probably led to formation of the "black shale" facies.
\end{abstract}

\section{INTRODUCTION}

Cretaceous black claystones were penetrated in DSDP Hole 534A between 764 and $950 \mathrm{~m}$ sub-bottom depths. Such a thick section was encountered owing to its location near the continental margin of the United States (Fig. 1).

Black claystones from the western North Atlantic drill sites all have broad compositional similarities, although there are local compositional peculiarities as well. The claystones from Sites 101, 105, 386, 387, 391, and 534 contain an average of $50 \%$ or more clay minerals, consisting primarily of smectite and illite, and 2 to $4 \%$ feldspars. Average quartz content is 10 to $20 \%$ in claystones at Sites 101 and 105 , and it is two to three times greater at Sites 386 and 387 (Tucholke and Vogt, 1979).

Detrital carbonaceous particles are common in Early Cretaceous black claystones drilled in the North Atlantic by the Deep Sea Drilling Project. At Site 391, the Aptian-Albian section contains abundant tracheal facies, composed of palynomorphs and palynodebris, which are compositionally close to those of coeval fluviodeltaic sediments on continents bordering the North Atlantic, except that marine currents sorted sporomorph species and admixed dinoflagellates prior to deposition (Habib, 1979). It is suggested that they were deposited by turbidity currents from the fluviodeltaic source.

Rapid termination of euxinic black clay deposition in the North Atlantic is indicated by the abrupt transition from black claystone to variegated claystone in the Plantagenet Formation, deposited near the end of the Cenomanian. Rejuvenated deep circulation could have been caused by any one of several potential new bottom-water sources. Exchange of deep water with the South Atlantic is one of the most likely causes.

\footnotetext{
${ }^{1}$ Sheridan, R. E., Gradstein, F. M., et al., Init. Repts. DSDP, 76: Washington (U.S. Govt. Printing Office).
}

\section{MAJOR CYCLES OF CARBONACEOUS CLAYSTONE IN THE HATTERAS FORMATION}

Downhole variation in abundance of carbonaceous claystones (black shale), and frequency per meter of graded units of both calciturbidites and quartz-silt layers have been examined in the Hatteras Formation; the interval spans Cores 24 through 46 . The result is shown in Figure 2. In order to plot the percentage of carbonaceous claystone per core, careful visual and microscopic observations of the core samples were conducted. The claystones containing more than $5 \%$ plant debris on the smear slide were classified as carbonaceous in this study. Figure 2 shows four major abundance peaks of carbonaceous claystone; these are at depths of $785 \mathrm{~m}$ (Core 29), $830 \mathrm{~m}$ (Core 34), $880 \mathrm{~m}$ (Core 39), and $915 \mathrm{~m}$ (Core 43).

Core 29 contains relatively high percentages of carbonaceous claystone, and these claystones are homogeneous with very few silt stringers. When the cores were split, some of the claystones were shiny and glittering black (N1) and appeared to contain high percentages of amorphous plant debris, an observation later confirmed by microscopic examination. Although the precise age of the claystone in Core 29 is not yet known, it is tentatively dated as Albian (Site 534 report, this volume).

The peak of carbonaceous claystone abundance in Core 34 is dated as middle Albian. These carbonaceous claystones are dark gray (N3) to greenish black (5Gy $1 / 2)$. Some contain greenish gray (5GY 6/1) stringers consisting mostly of quartz and feldspar, which tend to dilute the concentration of organic carbon. The quartzsilt stringers are less than a millimeter thick, and some show wavy lamination or Flaser-type lamination; they occur in both carbonaceous claystones and the interbedded silty claystones. The origin of the quartz stringer has not yet been determined, but possibilities are being considered. One is a "shower" of terrigenous materials from very weak turbidity currents. Another possibility involves bottom traction-current activity such as a contour current. The presence of wavy laminae less than a 


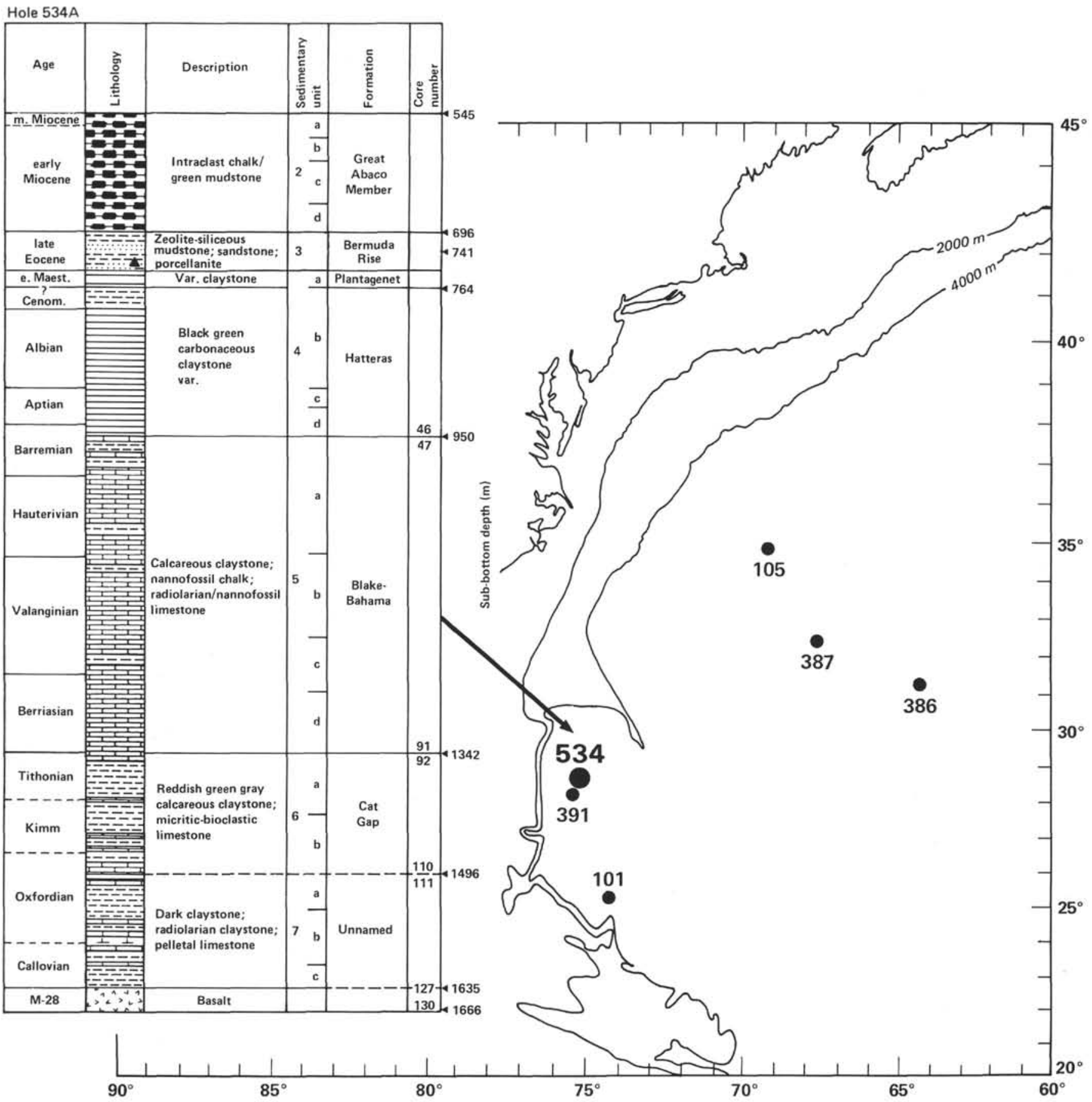

Figure 1. Location of Site 534 in the Blake-Bahama Basin of the western North Atlantic, and a generalized geologic columnar section of Hole 534A.

millimeter in size in the burrowed silty claystone may support this contention.

Thin turbidites consisting of recrystallized calcite and quartz and showing Bouma-sequence structures also occur in Core 34. Calcilutites up to $10 \mathrm{~cm}$ in thickness show normal-size grading. They occur in greatest abundance in Core 34, as shown in Figure 2. The source of the calciturbidites was probably the upper continental slope above the CCD (calcite compensation depth), where a supply of carbonates was more likely available.
The major abundant peak of carbonaceous material in Core 39 occurs in Albian rocks. The carbonaceous claystones are olive black (5Y 2/1) to black (N1) and fairly homogeneous, indicating relatively high organic carbon content. Although quartz stringers appear in the black portions, they are more abundant in the interbedded silty claystones. The lower part of each carbonaceous claystone tends to be homogeneous, whereas the upper part is commonly laminated, with occasional quartz stringers, which may suggest en masse input of 


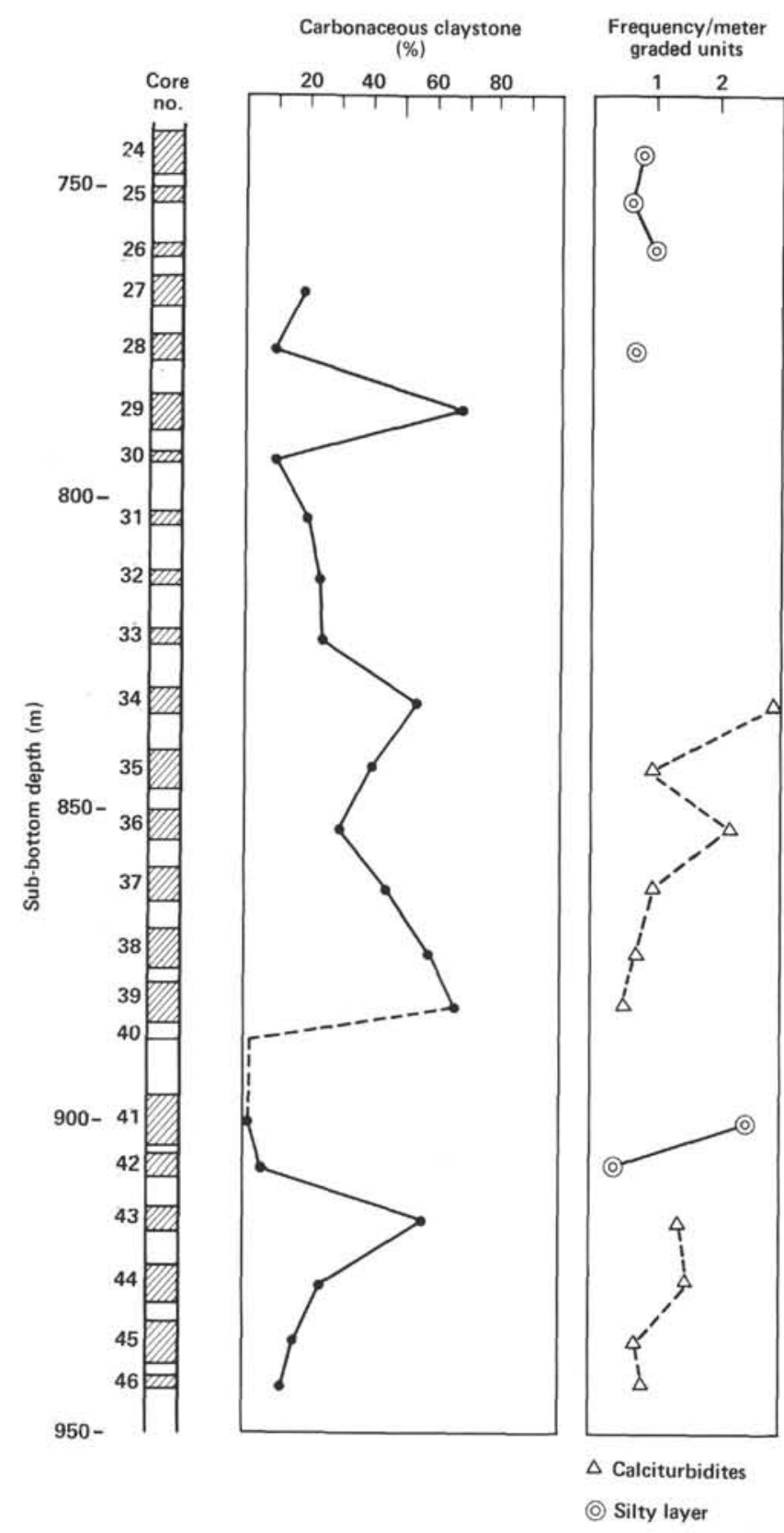

Figure 2. Downhole variation in abundance of carbonaceous claystones and graded layers in the Hatteras Formation. (The recovery frequency in numbers per meters of graded beds of calciturbidites [dashed line] and silty layers [solid line] is shown in the right column.)

carbonaceous matter, with later dilution by normal ocean-bottom processes. Smear-slide observation indicates concentration of amorphous organic matter in the bottom part of these beds.

The carbonaceous claystone frequency peak in Core 43, the lowest in the Hatteras Formation, has not been dated, but the age may be early Aptian, as in Core 44 . The carbonaceous claystone is greenish black $(5 \mathrm{G} 2 / 1)$ to dark gray (N3), less commonly grayish black (N2), similar to the Core-34 type with stringers. Calciturbidites with pelletal texture are abundant in early Aptian rocks. These rocks are also characterized by a gradual upward decrease of laminated calcareous claystones, which shows that the site subsided gradually below the $\mathrm{CCD}$. There are no radiolarian sands within the carbonaceous claystones. Chalcedonic quartz bands in the carbonaceous claystones have been observed only in Core 48, dated Barremian and older.

Intervals between the four major abundance peaks of carbonaceous claystone represent silty claystone deposition, including deposition of variegated claystones. Silty layers with current laminations occur only in the variegated intervals without calciturbidites. Because the silty layers and the variegated claystones have the same mineralogical composition, their deposition is likely linked. Several hypotheses are considered with respect to environment of deposition of the silty layer: (1) Calciturbidites were deposited in this stratigraphic interval but dissolved completely to leave the silty layers during or after deposition. (2) The CCD falls considerably in the water column so that calcium carbonate deposition decreased on the slope, with none on the basin floor; therefore, overburden was insufficient to cause slumping of carbonate sediments on the slope. (3) Silty turbidites were deposited by relatively weak turbidity currents flowing along the bottoms of canyons, so that no contamination with carbonates took place. (4) Oxygenated bottom currents winnowed bottom sediment to form the silty layer. The oxygen-rich waters could also have caused plant debris to be destroyed or diluted. Owing to an equable climate with the smooth surface temperature gradient in the ocean during the middle Cretaceous, sluggish deep circulation was suggested by Fischer and Arthur (1977). Therefore, another current mechanism such as a Rossby current could be expected to have existed in this portion of the continental margin.

\section{ORGANIC CARBON STABLE ISOTOPE RATIOS}

Stable isotope ratios $\left(\delta \mathrm{C}^{13}\right)$ of total organic carbon were measured in closely spaced samples from the Hatteras Formation at Hole 534A. Figures 3 and 4 show the position within the cores of 23 samples studied. Samples were thawed and treated with $0.5 \mathrm{~N}$ hydrochloric acid to remove carbonate carbon, then dried in air at room temperature. They were burned in a stream of pure oxygen at a temperature of $1000^{\circ} \mathrm{C}$ for $120 \mathrm{~min}$. to yield $\mathrm{CO}_{2}$. The evolved gas was passed through hot copper oxide, manganese oxide, and silver grains to remove impurities. The organic carbon content was determined by combusting a weighed residual sample and measuring manometrically the volume of purified gas. The carbon isotopic composition of the $\mathrm{CO}_{2}$ collected was analyzed in a Nier-Mackinney-type mass spectrometer (Varian Mat 250) (Ishizuka, 1978).

The results are given in parts per thousand from the PDB Chicago standard used by Craig (1957). The results indicate strongly terrestrial values of $\delta \mathrm{C}^{13}$, in the range of -26.8 to $-23.8 \%$ (Table 1 ). At the present time, terrestrially derived organic matter appears to play only a small part in determining the $\delta \mathrm{C}^{13}$ content of the total organic carbon in continental margin sediments. Offshore from areas of heavy runoff and sediment input, 


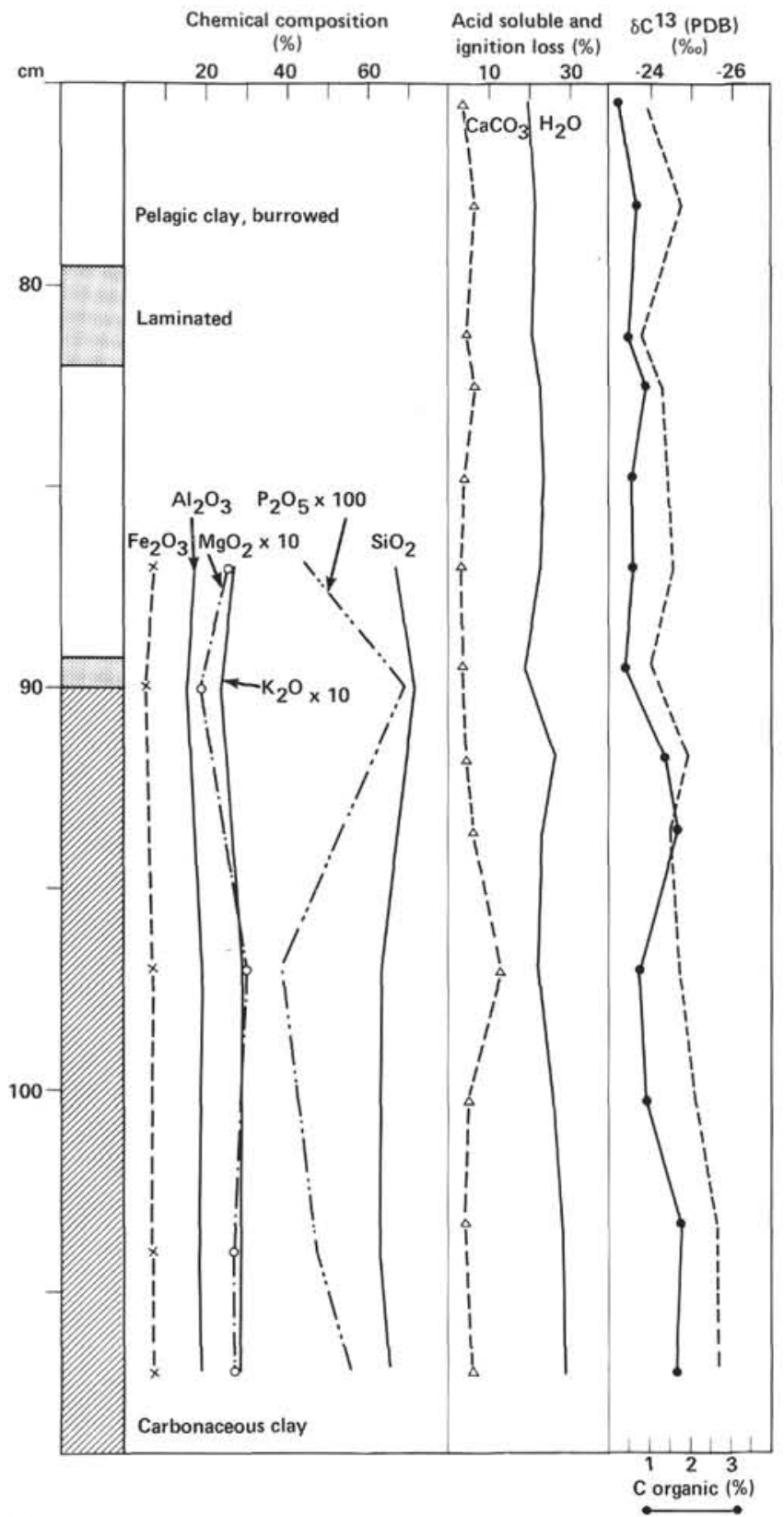

Figure 3. Major element analytical data and organic carbon stable isotope ratios in Core 29, Section 2, Hole 534A. (In the right column, the $\delta C^{13}$ ratio is shown by the dashed line, and organic carbon content by the solid line.)

such as the Mississippi and Niger deltas, the $\delta \mathrm{C}^{13}$ values range from terrigenous-influenced (around $-24 \%$ ) to typically marine $(-20 \%$ ) within a few tens of kilometers from shore (Gearing et al., 1977). The only locations where very negative, terrestrial isotope ratios (around $-26 \%$ ) were recorded were in rivers, such as the Amazon river, of hot and humid equatorial regions and in a $100 \mathrm{~km}$ inland canal along the Gulf of Mexico. Even here the sediment $\delta \mathrm{C}^{13}$ changed from $-26.6 \%$ o to $-23.9 \%$ while still in fresh water in the canal (Gearing et al., 1977).

From these observations, it is concluded that the paleoclimate during the Early Cretaceous was very different from the present climate and that a much greater

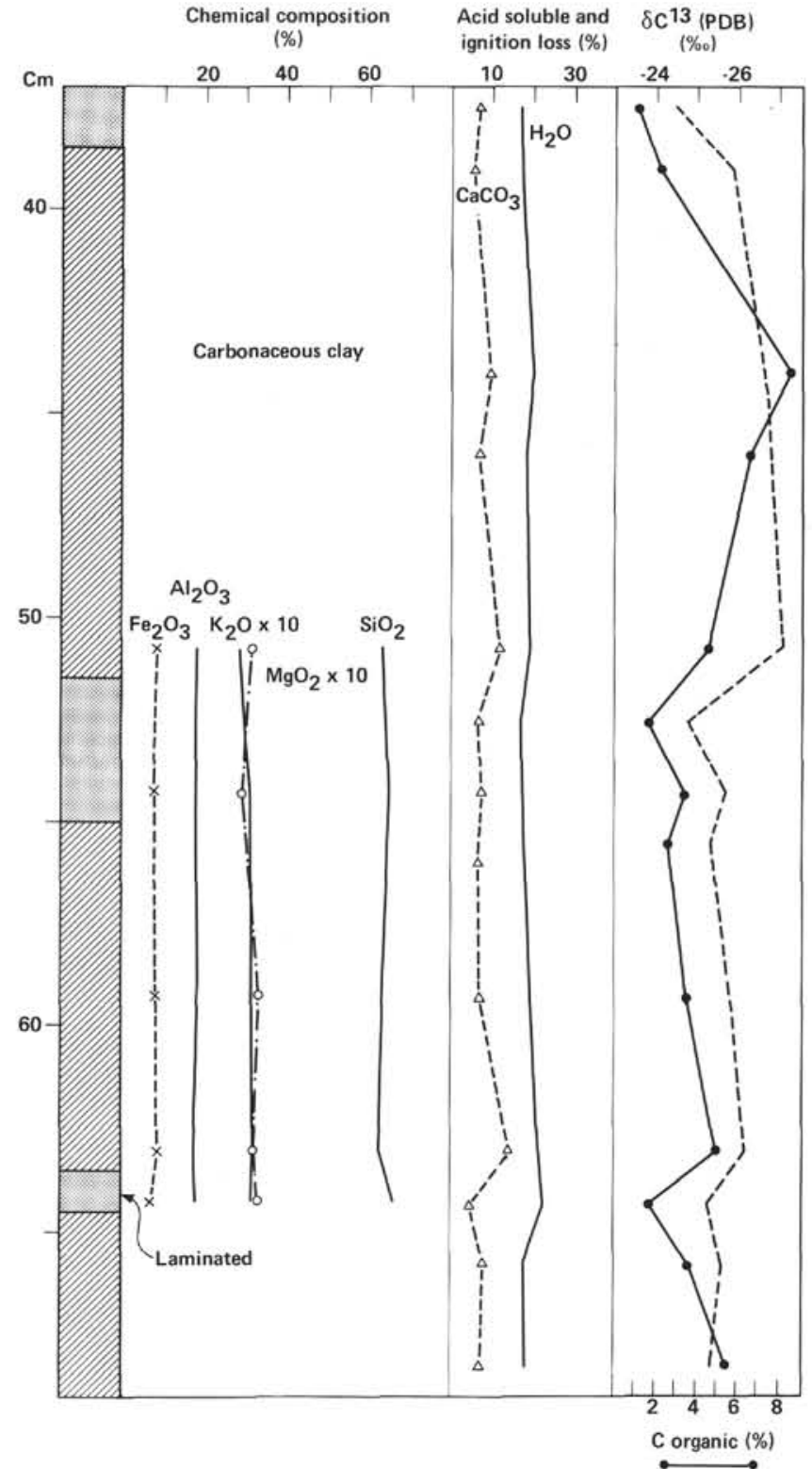

Figure 4. Major element analytical data and organic carbon stable isotope ratios in Core 39, Section 5, Hole 534A.

amount of terrestrial organic matter was incorporated into the continental margin sediments of that time. Assuming that tropical conditions prevailed during the Early Cretaceous favoring dense forests along the coast and that there was a heavy influence of land runoff toward the ocean basins seems fully justified.

\section{MAJOR ELEMENT CONTENT}

After grinding samples to a fine powder, we heated the samples at a temperature of $1000^{\circ} \mathrm{C}$ for $90 \mathrm{~min}$. Therefore the analyzed data are given on a carbonateand water-free basis.

Major element content was determined using fused disc samples by an automatic X-ray fluorescence spectrometer (Rigaku 1KF 3064) connected to a microcomputer (Nova 01) at the Geological Institute, University of Tokyo (Matsumoto and Urabe, 1980). Analyses made 
Table 1. Organic carbon stable isotope ratios.

\begin{tabular}{|c|c|c|c|c|}
\hline $\begin{array}{l}\text { Depth from } \\
\text { top of section } \\
(\mathrm{cm})\end{array}$ & $\underset{(\%)}{C \text { organic }}$ & $\begin{array}{c}\delta C^{13} \text { PDB } \\
(\%)\end{array}$ & $\begin{array}{c}0.5 N \\
\text { HCl-soluble } \\
\left(\mathrm{CaCO}_{3} \%\right)\end{array}$ & $\begin{array}{c}\text { Water } \\
\text { content } \\
(\%)\end{array}$ \\
\hline \multicolumn{5}{|c|}{ Core 29, Section 2} \\
\hline $75.0-76.0$ & $0.025 \pm 0.02$ & $-23.9 \pm 0.1$ & 3.5 & 19.9 \\
\hline $77.5-78.5$ & $0.069 \pm 0.02$ & $-24.7 \pm 0.2$ & 6.2 & 21.1 \\
\hline $81.0-81.5$ & $0.45 \pm 0.02$ & $-23.8 \pm 0.1$ & 4.1 & 20.2 \\
\hline $82.0-83.0$ & $0.87 \pm 0.03$ & -24.2 & 6.2 & 22.5 \\
\hline $84.5-85.0$ & $0.52 \pm 0.01$ & $-24.4 \pm 0.2$ & 3.5 & 23.4 \\
\hline $86.5-87.5$ & $0.56 \pm 0.02$ & $-24.5 \pm 0.2$ & 3.0 & 22.3 \\
\hline $89.0-90.0$ & $0.33 \pm 0.01$ & $-24.0 \pm 0.1$ & 3.3 & 18.2 \\
\hline $91.5-92.0$ & $1.37 \pm 0.01$ & -24.9 & 4.0 & 25.4 \\
\hline $93.0-94.0$ & $1.61 \pm 0.04$ & $-24.5 \pm 0.3$ & 6.7 & 23.0 \\
\hline $96.5-97.5$ & $0.73 \pm 0.02$ & $-24.7 \pm 0.0$ & 13.4 & 21.9 \\
\hline $100.0-100.5$ & $0.97 \pm 0.03$ & $-24.9 \pm 0.3$ & 4.4 & 25. \\
\hline $103.0-103.5$ & $1.74 \pm 0.06$ & $-25.6 \pm 0.0$ & 3.6 & 28.4 \\
\hline $106.5-107.0$ & $1.65 \pm 0.01$ & $-25.7 \pm 0.1$ & 5.2 & 27.9 \\
\hline \multicolumn{5}{|c|}{ Core 39 , Section 5} \\
\hline $37.0-38.0$ & $1.03 \pm 0.11$ & $-24.4 \pm 0.1$ & 6.5 & 16.1 \\
\hline $38.0-40.0$ & $2.13+0.35$ & $-25.8+0.1$ & 5.9 & 15.9 \\
\hline $43.0-45.0$ & $8.41 \pm 0.64$ & $-26.6 \pm 0.1$ & 9.9 & 19.2 \\
\hline $45.0-47.0$ & $6.49 \pm 0.09$ & $-26.8 \pm 0.1$ & 6.3 & 18.6 \\
\hline $50.0-51.5$ & $4.33+0.46$ & -27.1 & 11.4 & 18.4 \\
\hline $51.5-53.5$ & $1.66 \pm 0.08$ & -24.8 & 6.9 & 17.2 \\
\hline $53.5-55.0$ & $3.29 \pm 0.04$ & $-25.6 \pm 0.1$ & 7.1 & 19.6 \\
\hline $55.2-56.7$ & $2.58+0.05$ & $-25.3 \pm 0.1$ & 6.7 & 18.1 \\
\hline $58.5-60.0$ & $3.55 \pm 0.00$ & $-25.8 \pm 0.1$ & 6.9 & 19.2 \\
\hline $62.0-63.7$ & $5.05 \pm 0.03$ & $-26.2 \pm 0.1$ & 14.2 & 20.2 \\
\hline $63.7-64.8$ & $1.86 \pm 0.21$ & $-25.3 \pm 0.1$ & 4.6 & 22.2 \\
\hline $64.8-66.5$ & $3.67 \pm 0.07$ & $-25.6 \pm 0.0$ & 7.3 & 17.4 \\
\hline $66.5-68.5$ & $5.55 \pm 1.86$ & $-25.3 \pm 0.1$ & 7.1 & 18.4 \\
\hline
\end{tabular}

on a total of 15 black shales from Site 534 are given in Table 2 and Figures 3 and 4.

Analyzed data show substantial differences in black shales between the Hatteras and Blake-Bahama formations. Black shales in the Blake-Bahama Formation (Core 48, Section 5 in Table 2) are intercalated in nannofossil chalk composed dominantly of calcium carbonate. Interbedded black shales have more detrital fractions composed of kaolinite and quartz, and show relative abundance of silica and alumina. The black shales could have been deposited by turbidity currents resulting from the erosional activity on the continent or eustatic change in sea level (de Graciansky et al., 1979). Or intercalation of calcium carbonate might have been controlled by periodical change in biogenic productivity in the sea (Mèliéres, 1979). This type of black shale with calcium carbonate cyclicity has been reported from the Bay of Biscay (Mèliéres, 1979).

Black shales in the Hatteras Formation show, on the other hand, significant concentration of silica and alumina and no obvious cyclicity of calcium carbonates or other elements. There are remarkable concentrations in organic carbon associated with smectite, which is observed in Core 39, Section 5 (Fig. 5). This type of black shale is characterized by high concentration of organic carbon and very fine grains of detrital matter.

In Core 29 , Section 2, it is observed that silica concentrates significantly in the pelagic clay interval (Fig. $3)$. This characteristic is interpreted to mean that deposition of terrigenous organic carbon was interrupted by renewed sea-bottom circulation, and as a result winnowed residuals of quartz-silt stringers were deposited. Organic carbon is not significantly concentrated in this type of black shale, and observed relative abundances of illite and kaolinite are indicative of terrigenous origins for this interval.

\section{CLAY MINERALOGY}

Forty-one samples from Cores 29,39 , and 48 were collected for clay mineral investigation. Core 29 , Section 2 and Core 39, Section 5 are composed of carbonaceous claystone, and Core 48 , Section 5 is calcareous claystone or nannofossil chalk. The core samples range in age from middle to Early Cretaceous; samples from Core 29, Section 2 are Albian, those from Core 39, Section 5 range from the Aptian to the Albian, and samples from Core 48, Section 5 are Barremian.

Each sample was first soaked in distilled water to soften, then ground in an agate mortar, and again dispersed in distilled water. Then the clay-size fraction smaller than $2 \mu \mathrm{m}$ was collected by sedimentation. Quan-

Table 2. Major element analyses.

\begin{tabular}{|c|c|c|c|c|c|c|c|c|c|c|c|}
\hline $\begin{array}{l}\text { Depth from } \\
\text { top of section } \\
(\mathrm{cm})\end{array}$ & $\mathrm{SiO}_{2}$ & $\mathrm{TiO}_{2}$ & $\mathrm{Al}_{2} \mathrm{O}_{3}$ & $\mathrm{Fe}_{2} \mathrm{O}_{3}$ & $\mathrm{MnO}$ & $\mathrm{MgO}$ & $\mathrm{CaO}$ & $\mathrm{Na}_{2} \mathrm{O}$ & $\mathrm{K}_{2} \mathrm{O}$ & $\mathrm{P}_{2} \mathrm{O}_{5}$ & Total \\
\hline \multicolumn{12}{|l|}{ Core 29 , Section 2} \\
\hline $\begin{array}{c}86.5-87.5 \\
89.0-91.0 \\
96.5-97.5 \\
103.5-106.5 \\
106.5-107.0\end{array}$ & $\begin{array}{l}66.211 \\
71.547 \\
63.643 \\
62.514 \\
65.679\end{array}$ & $\begin{array}{l}0.884 \\
0.900 \\
0.948 \\
0.912 \\
0.941\end{array}$ & $\begin{array}{l}17.180 \\
15.526 \\
19.312 \\
18.930 \\
19.399\end{array}$ & $\begin{array}{l}7.578 \\
5.660 \\
7.606 \\
7.930 \\
7.984\end{array}$ & $\begin{array}{l}0.006 \\
0.004 \\
0.026 \\
0.012 \\
0.007\end{array}$ & $\begin{array}{l}2.523 \\
1.911 \\
3.002 \\
2.779 \\
2.775\end{array}$ & $\begin{array}{l}0.568 \\
0.601 \\
0.545 \\
0.631 \\
0.645\end{array}$ & $\begin{array}{l}2.275 \\
2.508 \\
2.353 \\
2.125 \\
2.117\end{array}$ & $\begin{array}{l}2.618 \\
2.387 \\
2.950 \\
2.867 \\
2.888\end{array}$ & $\begin{array}{l}0.045 \\
0.069 \\
0.039 \\
0.048 \\
0.056\end{array}$ & $\begin{array}{r}99.888 \\
101.113 \\
100.424 \\
98.748 \\
102.491\end{array}$ \\
\hline \multicolumn{12}{|l|}{ Core 39 , Section 5} \\
\hline $\begin{array}{l}50.0-51.5 \\
53.5-55.2 \\
58.5-60.0 \\
62.0-63.7 \\
63.7-64.8\end{array}$ & $\begin{array}{l}63.183 \\
64.547 \\
62.972 \\
62.570 \\
65.372\end{array}$ & $\begin{array}{l}0.894 \\
0.899 \\
0.892 \\
0.889 \\
0.896\end{array}$ & $\begin{array}{l}17.750 \\
17.569 \\
18.068 \\
17.885 \\
18.114\end{array}$ & $\begin{array}{l}8.174 \\
7.845 \\
8.017 \\
8.767 \\
7.276\end{array}$ & $\begin{array}{l}0.022 \\
0.025 \\
0.029 \\
0.018 \\
0.020\end{array}$ & $\begin{array}{l}3.034 \\
2.920 \\
3.260 \\
3.194 \\
3.253\end{array}$ & $\begin{array}{l}0.596 \\
0.666 \\
0.666 \\
0.797 \\
0.589\end{array}$ & $\begin{array}{l}1.964 \\
2.012 \\
1.882 \\
2.056 \\
2.253\end{array}$ & $\begin{array}{l}2.990 \\
3.043 \\
3.189 \\
3.170 \\
3.178\end{array}$ & $\begin{array}{l}0.086 \\
0.084 \\
0.087 \\
0.084 \\
0.048\end{array}$ & $\begin{array}{r}98.693 \\
99.610 \\
99.062 \\
99.430 \\
100.999\end{array}$ \\
\hline \multicolumn{12}{|l|}{ Core 48 , Section 5} \\
\hline $\begin{array}{l}70.8-72.5 \\
75.5-78.0 \\
80.0-81.5 \\
83.0-83.5 \\
85.5-87.0\end{array}$ & $\begin{array}{r}19.385 \\
57.415 \\
39.337 \\
63.793 \\
4.191\end{array}$ & $\begin{array}{l}0.151 \\
0.408 \\
0.284 \\
0.108 \\
0.092\end{array}$ & $\begin{array}{r}4.605 \\
10.332 \\
7.851 \\
2.368 \\
2.598\end{array}$ & $\begin{array}{l}1.661 \\
6.674 \\
2.271 \\
0.957 \\
1.544\end{array}$ & $\begin{array}{l}0.055 \\
0.009 \\
0.017 \\
0.038 \\
0.065\end{array}$ & $\begin{array}{l}0.957 \\
1.903 \\
1.569 \\
0.471 \\
0.699\end{array}$ & $\begin{array}{l}56.308 \\
16.353 \\
38.852 \\
31.960 \\
65.962\end{array}$ & $\begin{array}{l}0.502 \\
1.253 \\
1.206 \\
0.550 \\
0.238\end{array}$ & $\begin{array}{l}0.291 \\
1.655 \\
0.656 \\
0.339 \\
0.144\end{array}$ & $\begin{array}{l}0.102 \\
0.055 \\
0.166 \\
0.059 \\
0.101\end{array}$ & $\begin{array}{c}(84.017) \\
96.057 \\
92.209 \\
100.643 \\
(75.634)\end{array}$ \\
\hline
\end{tabular}




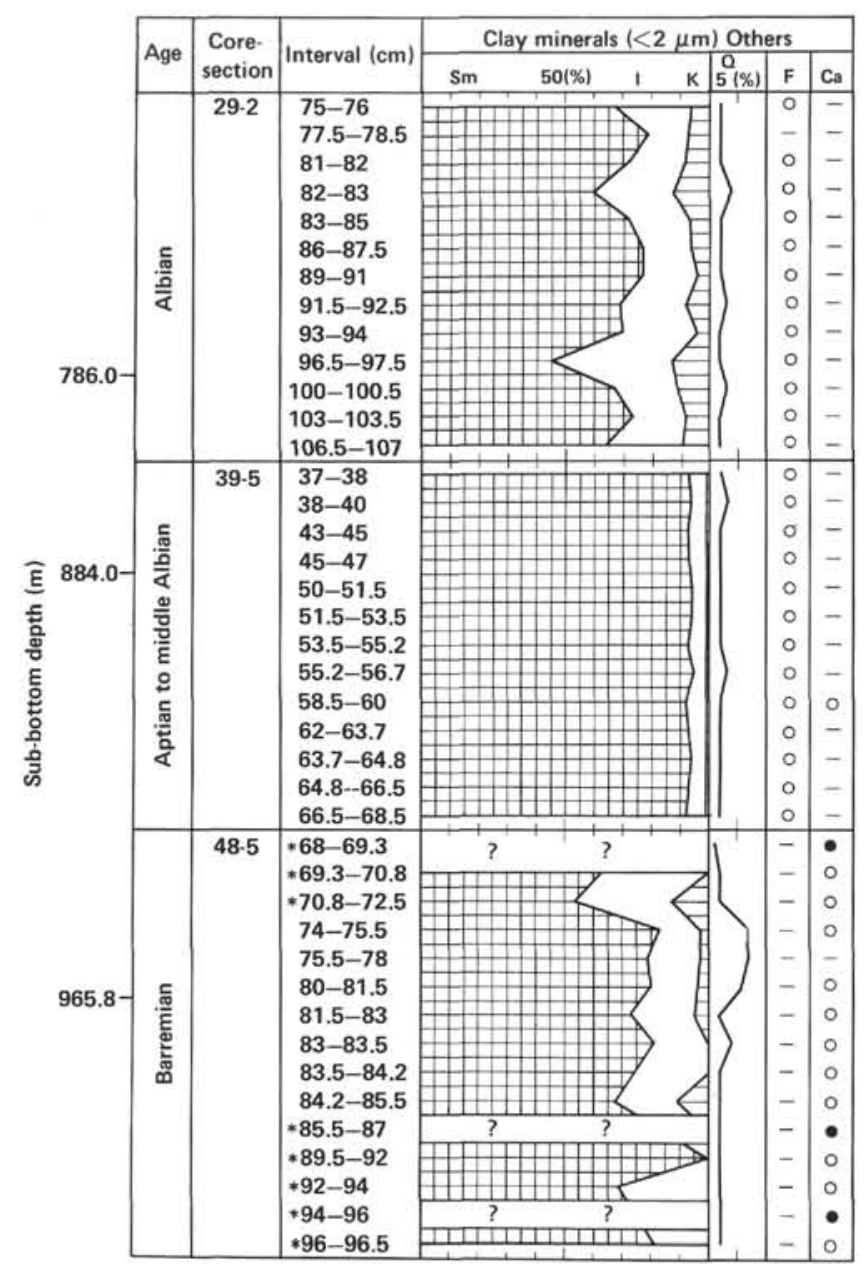

Figure 5. Composition of clay minerals in the clay fractions $(<2 \mu \mathrm{m})$. ( $\mathrm{Sm}=$ smectite, $\mathrm{K}=$ kaolinite, $\mathrm{F}=$ feldspar, $\mathrm{I}=$ illite, $\mathrm{Q}=$ quartz, $\mathrm{Ca}=$ calcite, ${ }^{*}=$ no quantification of clay minerals, $-=$ absent, $\mathrm{O}=$ present, and $\bullet$ = very abundant.)

titative and qualitative estimations of clay minerals were made following the method reported by Sudo et al. (1961) and Oinuma (1968).

$\mathrm{X}$-ray diffraction analysis revealed the presence of smectite, illite, and kaolinite, but chlorite, which is widely prevalent in oceanic sediments (Griffin et al., 1968; Rateev et al., 1969; and Aoki et al., 1974), was not identified. Nonclay minerals such as quartz, feldspar, and calcite were also identified in the clay fraction. X-ray diffraction patterns are shown in Figure 6. Quartz is found in all samples, and feldspar occurs in most samples from Core 29, Section 2 and Core 39, Section 5, but not in Core 48, Section 5 samples. Calcite occurs only in samples of Core 48, Section 5. Clay mineral composition of samples from the three cores appears in Figure 5.

In Core 29, Section 2 (Albian) smectite is the predominant clay mineral. The content of smectite ranges from 45 to $79 \%$, with an average of $69 \%$. Change in smectite concentration vertically in the cores is variable. The content of illite ranges from 14 to $42 \%$, and is $23 \%$ on the average. The change in illite abundance vertically is also variable. The content of kaolinite ranges from 4 to $12 \%$, with an average of $8 \%$. Kaolinite is widely distributed,
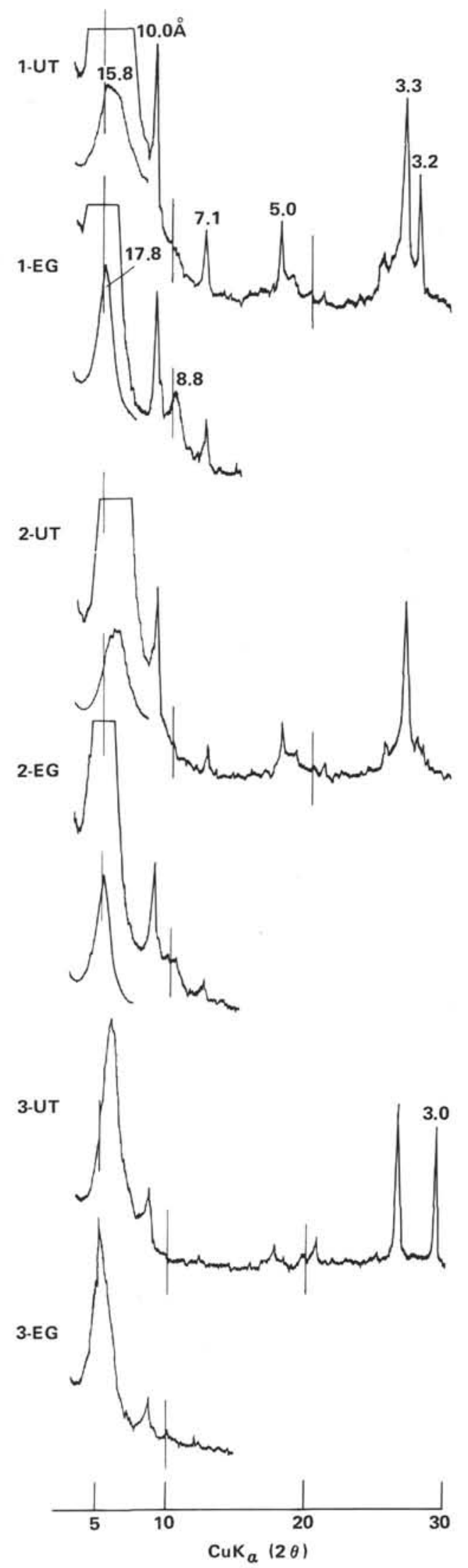

Figure 6. X-ray diffraction patterns of selected samples. (1. Sample 534A-29-2, 81-82 cm; 2. Sample 534A-39-5, 37-38 cm; 3. Sample $534 \mathrm{~A}-48-5,80-81.5 \mathrm{~cm}$; UT $=$ untreated sample; and EG = ethylene glycol.) 
though in small amounts. The content of quartz ranges from 2 to $4 \%$, and is $2 \%$ on the average.

In Core 39, Section 5 (Aptian-Albian) smectite is by far the dominant clay mineral. The content of smectite ranges from 92 to $95 \%$; it is $93 \%$ on the average. The content of illite ranges from 4 to $7 \%$, with an average of $6 \%$. Kaolinite occurs in trace amounts. The average content of quartz is $2 \%$.

Core 48 , Section 5 (Barremian) is characterized by calcareous claystone. Seven of 15 available samples have size fractions coarser than $2 \mu \mathrm{m}$. Because of the dilution effect of a great quantity of calcite in these coarse size fractions, clay minerals in these samples have not been quantitatively analyzed. Core 48 , Section 5 is also characterized by the predominance of smectite, which ranges from 54 to $100 \%$ and is $75 \%$ on the average. The content of illite ranges from 0 to $33 \%$ and is $21 \%$ on the average. Kaolinite concentration ranges from 0 to $13 \%$, with an average of $4 \%$. The average content of quartz is $3 \%$. Calcite is present in all but one sample.

In summary, the clay mineralogy of 41 sediment samples from Hole 534A, ranging in age from the Barremian to the Albian, was determined by X-ray diffraction. Smectite is the dominant clay mineral throughout the cores, particularly in Core 39, Section 5 (AptianAlbian), in which it makes up more than $90 \%$ of the clay minerals in the samples. The smectite in these samples is not an iron-rich montmorillonite, such as occurs widely in the Pacific deep-sea sediments (Aoki et al., 1974 and 1979), but an aluminous montmorillonite like that prevailing on the continent. This interpretation is confirmed by analyses in which the smectite remained as a phase of hydrogen montmorillonite at 12 to $13 \AA$ in the diffractogram after being heated at $95^{\circ} \mathrm{C}$ for 30 min. with $6 N \mathrm{HCL}$. Terrigenous origin of the smectite is also suggested by the occurrence of associated terrigenous minerals. On the basis of many analyses of Atlantic DSDP samples, Chamley (1979) reported that Cretaceous smectite is mostly of terrigenous origin.

\section{DISCUSSION}

Information derived from palynology, vitrinite reflectance, pyrolysis, and other studies of kerogen and extractable organic matter have shown that nearly all of the organic matter in Lower Cretaceous, dark-colored sediment was derived from terrestrial plants with some contribution of second-cycle organic carbon, possibly derived from eroded coal deposits (Habib, 1979; Tissot et al., 1979). Only in Cenomanian dark-colored claystones does more hydrogen-rich organic matter of marine derivation make up a significant part of the total organic material (Tissot et al., 1979).

There are one or more possible reasons for insignificant preservation of more hydrogen-rich organic matter under anoxic conditions that might have existed at least periodically elsewhere in the North Atlantic in the Barremian to middle Albian: (1) overall sea-surface productivity in this part of the North Atlantic was very low; (2) conditions were not anoxic in bottom waters in this portion of the North Atlantic, and more reactive organic matter was oxidized on the seafloor before and during the early phases of burial; and occurrence of siderite is evidence of consumption of organic matter during reduction of sulfate; or (3) the high rate of influx of terrigenous organic matter led to diminished expression of the pelagic marine contribution (Arthur, 1979).

An interesting aspect of the paleoenvironment at Site 534 is the apparent subsidence of the seafloor at the site below the CCD level (or rise of the CCD) during the early Aptian (Shipboard Party, 1981). Sedimentation of pelagic carbonate occurred before deposition of the BlakeBahama Formation. Terrigenous sediment dilution beginning from the early Aptian is one important facet of the CCD problem. It is also possible that the paucity of carbonate in North Atlantic sites is due, in addition to dilution and diagenetic factors, to low sea-surface fertility, fluctuating salinities, and increased turbidity owing to major deltaic progradation into a somewhat restricted basin. By the late Albian to the early Cenomanian, marine transgression and possibly climatic changes had resulted in cessation of most deltaic outbuilding and trapping of terrigenous materials on shelves and in interior basins (Jansa and Wade, 1975).

Deposition of carbonaceous claystones in marine environments occurred dominantly during the early Aptian to middle Albian at Hole 534A. Almost all organic carbon in these sequences has very negative terrestrial isotope ratios. Development of coastal vegetation belts with consequent large outpourings of terrigenous clastics and land-plant detritus in a hot, humid, equatorial climate probably led to formation of the "black shale" facies. There is very good correlation between the $\delta \mathrm{C}^{13}$ and the organic carbon content of samples, as shown in Figures 3 and 4, which is additional evidence of terrigenous influx. Clay mineral analysis of rocks of that age (Core 39, Section 5) indicates predominance of an aluminous montmorillonite-type smectite thought to be of terrigenous origin. Abundance of smectite associated with kaolinite, and the absence of a mixed-layer clay mineral of illite-smectite might indicate sufficient hydrolysis to permit the development of smectite and kaolinite on the continent.

Quartz-silt layers were discovered by the major element analyses (89.0-91.0 cm in Core 29, Section 2-Fig. 3 ), in which $\mathrm{SiO}_{2}$ content reaches $71.5 \%$. Other than these silt layers, Aptian-Albian black shales do not show any remarkable variations in chemical composition. On the contrary, Barremian black shales show remarkable cyclicity, owing to interbedded carbonates. Black shales have up to $7 \%$ quartz in the clay fraction. No feldspar was observed in this core (Core 48 , Section 5), suggesting that the quartz may be transformed from biogenic silica. The presence of radiolarian micrites in thin sections of the core samples (Site 534 report) supports this suggestion.

\section{ACKNOWLEDGMENTS}

We thank the Japanese IPOD committee for their efforts in joining Leg 76. We gratefully acknowledge the support of Professor Noriyuki Nasu (Ocean Research Institute, University of Tokyo), Professor Kaoru Oinuma (Toyo University), Dr. Ryo Matsumoto (Geological Institute, University of Tokyo), and Dr. Masato Nohara and Dr. Yukihiro Matsuhisa (Geological Survey of Japan) during preparation of the 
manuscript. Professor Noriyuki Nasu, and Professor Sam Boggs, Jr. (Department of Geology, University of Oregon) read the manuscript. We thank Mr. K. Sugi for making sample glass holders. Ms. Chitani Harayama kindly prepared the manuscript.

\section{REFERENCES}

Aoki, S., Koyama, N., and Sudo, T., 1974. An iron-rich montmorillonite in a sediment core from the northeastern Pacific. Deep-Sea Res., 21:865-875.

1979. Mineralogical and chemical properties in a sediment core from the southeastern Pacific. Deep-Sea Res., 26(8A): 893-902.

Arthur, M. A., 1979. North Atlantic Cretaceous black shales. In Sibuet, J.-C., Ryan, W. B. F., et al., Init. Repts. DSDP, 47, Pt. 2: Washington (U.S. Govt. Printing Office), 719-752.

Chamley, H., 1979. North Atlantic clay sedimentation and paleoenvironment since the late Jurassic. In Talwani, M., Hay, W., and Ryan, W. B. F. (Eds.), Deep Drilling Results in the Atlantic Ocean. Am. Geophys. Union, Third Maurice Ewing Conference Volume, pp. $342-361$.

Craig, H., 1957. Isotopic standards for carbon and oxygen and correction factors for mass spectrometric analysis of carbon dioxide. Geochim. Cosmochim. Acta, 12:133-149.

de Graciansky, P. C., Auffret, G. A, Dupeuble, P., Montadert, L., and Müller, C., 1979. Interpretation of depositional environments of the Aptian/Albian black shales on the north margin of the Bay of Biscay. In Montadert, L., Roberts, D. G., et al., Init. Repts. DSDP, 48: Washington (U.S. Govt. Printing Office), 855-875.

Fischer, A. G., and Arthur, M. A., 1977. Secular variations in the pelagic realm. In Cook, H. E., and Enos, P. (Eds.), Deep Water Carbonate Environments, Soc. Econ. Paleontol. Mineral. Spec. Publ., 25:19-50.

Gearing, P., Plucker, F. E., and Parker, P. L., 1977. Organic carbon stable isotope ratios of continental margin sediments. Mar. Chem., 5:251-266.

Griffin, J. J., Windom, H., and Goldberg, E. D., 1968. The distribution of clay minerals in the world ocean. Deep-Sea Res., 15:433-459.

Habib, D., 1979. Origin and distribution of palynofacies in Cretaceous carbonaceous sediments of the North Atlantic. In Talwani, M.,
Hay, W., and Ryan, W. B. F. (Eds.), Deep Drilling Results in the Atlantic Ocean. Am. Geophys. Union, Third Maurice Ewing Conference Volume, pp. 420-437.

Ishizuka, T., 1978. Stable carbon isotope composition of organic material and carbonaceous in sediments of a swamp and lakes in Honshu Island, Japan. J. Earth Sci. Nagoya Univ., 25:11-21.

Jansa, L. F., and Wade, J. A., 1975. Geology of the continental margin off Nova Scotia and New Foundland. In van der Linden, W. J. M., and Wade, J. A. (Eds.), Offshore Geology of Eastern Canada, Geol. Surv. Can. Pap. 74-30, 2:51-105.

Matsumoto, R., and Urabe, T., 1980. An automatic analysis of major elements in silicate rocks with X-ray fluorescence spectrometer using fused disc samples. J. Jpn. Assoc. Mineral. Petrol. Econ. Geol., 75:272-278.

Mèliéres, F., 1979. Mineralogy and geochemistry of selected Albian sediments from the Bay of Biscay, DSDP Leg 48. In Montadert, L., Roberts, D. G, et al., Init. Repts. DSDP, 48: Washington (U.S. Govt. Printing Office), 855-875.

Oinuma, K., 1968. Method of quantitative estimation of clay minerals in the sediments by Z-ray diffraction analysis. J. Tokyo Univ., General Education Nat. Sci., 10:1-15.

Rateev, M. A., Gorbunova, Z. N., Lisitzn, A. P., and Nosov, G. L., 1969. The distribution of minerals in the oceans. Sedimentology, 13:21-43.

Shipboard Party, Leg 76, 1981. Challenger drills at sites off East Coast. Geotimes, Sept. 1981:23-25.

Sudo, T., Oinuma, K., and Kobayashi, K., 1961. Mineralogical problems concerning rapid clay mineral analysis of sedimentary rocks. Acta Univ. Carol. Geol. Suppl., 1:189-219.

Tissot, B., Deroo, B., and Hervin, J. P., 1979. Organic matter in Cretaceous sediments of the North Atlantic. In Talwani, M.,'Hay, W., and Ryan, W. B. F. (Eds.) Deep Drilling Results in the Atlantic Ocean. Am. Geophys. Union, Third Maurice Ewing Conference Volume, pp. 362-374.

Tucholke, B. E., and Vogt, P. R., 1979. Western North Atlantic: sedimentary evolution and aspects of tectonic history. In Tucholke, B. E., Vogt, P. R., et al., Init. Repts. DSDP, 43: Washington (U.S. Govt. Printing Office), 791-825.

Date of Initial Receipt: June 25, 1982 